Hala Mahmoud Mohammad Harby

\title{
Myth as Collective Memory in Wole Soyinka's Death and the King's Horseman
}

\author{
Hala Mahmoud Mohammad Harby \\ APhD student faculty of Education \\ Ain shams University
}

\section{Abstract}

Drawing on Memory Studies, the present paper investigates how the Nigerian poet, playwright and critic Wole Soyinka utilises myth as a type of collective memory in post-colonial Nigeria to call for a sense of national identity. Since the sixties of the last century, Memory Studies has become a solid approach, especially when linked to Post-Colonial Theory and Soyinka's theory of transition. 'Memory studies' allows history to be revealed from a diverse viewpoint apart from official history, while Soyinka's theory highlights change as the social role of theatre. This paper attempts to answer the following questions: What is collective memory? What is the relevance of collective memory in post-colonial societies? How can myth be considered a form of collective memory? How and why does Soyinka adhere to myth and its function as collective memory in Nigeria?

Keywords: Memory Studies- Marketplace, myth, collective memory, Soyinka's theory of transition, Post-colonial Context.

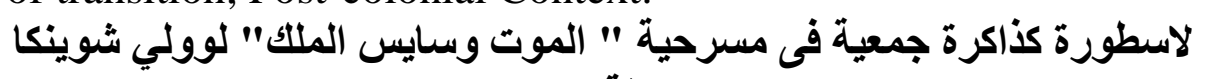

$$
\text { د/هالة حربى الهم }
$$

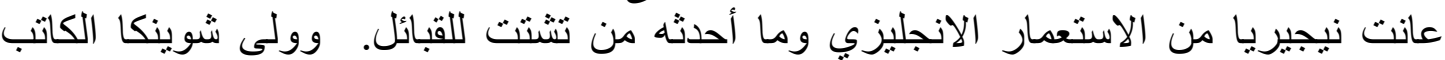

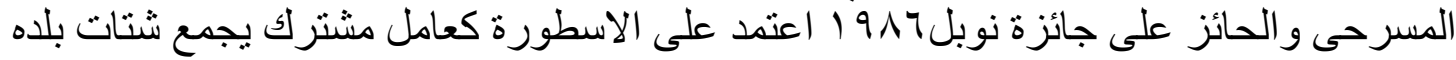

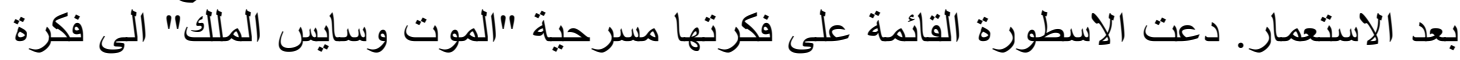

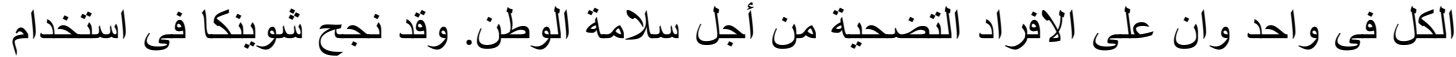

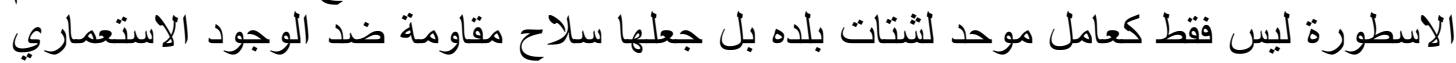

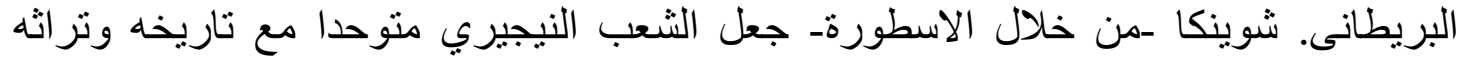
وذاكرته الجمعية ليقف في وجنه الاستعمار

Colonialism left Nigeria in fragments; different dialects, colliding tribes, and authoritarian regimes which caused coups, countercoups and massacres. Wole Soyinka as a committed writer and political activist excavated the national heritage to search for a unifying factor to gather his worn out nation. Myth is his target. All the conflicted tribes still not only believe in myth but live it as reality. Thus, Soyinka sticks to the only unifying factor: myth. From the myriad heritage of myth, Soyinka selects the patron god Ogun whose characteristics parallel with the phase Nigeria works through. Ogun is a rebel god who dares to pass the dark abyss between the deities and human beings. Ougn's deeds parallel with what Soyinka wants his country to act accordingly, especially when we know that Soyinka adheres to change as the social role of theatre. 'Memory Studies' is the approach to this paper in the sense that Soyinka recalls the myth as the collective memory of his nation. 'Memory Studies' is 
concerned with the unofficial, oral history where memory is shared by the ordinary people in 'a marketplace.'

Memory is defined as "the mental capacity or faculty of retaining and reviving facts, events, impressions, etc. ... or of recalling or recognizing previous experiences" (Online Dictionary.com). Memory is where we use past information for the benefit of the present. Most notably, memory seems to be "a source of knowledge so memory differs from perception" (Sutton 4). We remember events which really happened. John Sutton explains that "memory is unlike pure imagination yet, in practice, there can be close interaction between remembering, perceiving, and imagining."(5). Memory is a product of hybridity that combines the past experience and the imagination, perception, and awareness of the individual. Different factors colour the output of the recalled experience. Among these factors are perception, imagination and the time that separate the previous experience from the present. Perception and imagination indicate subjectivity which is not a default in humanities.

As for the nature of memory, it is commonly classified into one of two major categories: private/individual and public/ social/ cultural/collective. The individual is always the witness of what happened in the past. There is an agreement on the denotation of private/ individual memory. On the other hand, there is no consensus among social scientists, students of literature, and some philosophers on the preferred term for collective memory. In her article entitled, "Memory: Concepts and Practice" Judith Pollmann draws attention to the difference between collective, cultural and social memory. Pollmann clarifies that whereas Maurice Halbwachs (1877-1945) used the term "collective memory", many students of literature and some philosophers prefer the term "cultural memory". In addition, historians and social scientists prefer the term "social memory". This disagreement emerges due to the different approaches used to describe the term. While Halbwachs used sociological approach (based on categories such as family, religion, class), the students of cultural memory depend on the subconscious, and recollection to describe their tendency to the term. Students of "social memory" focused more on the interaction between the past and the present and social environment in shaping memory through remembrance (Pollmann). Overall, both private and public memories are similarly shaped by an interaction between oral and written sources, as well as ritual and material culture. Thus, we can conclude that collective, social, and cultural are all different descriptions/ perspectives of the same issue: a group memory.

Taking the argument a step further, Franco Ferrarotti (1926-), the father of the Italian sociology, postulates that private and collective 


\section{Hala Mahmoud Mohammad Harby}

memories are inseparable terms. To explain Janelle L. Wilson illustrates that for Ferrarotti, memory is not simply an individual question:

Memory has a base in and a link with the community...it involves the group, the collective unconscious, a stream of unconsciousness which links everything and travels into the interior of everyone at variable speeds and with its own images without, thus, exclusively belonging to anyone. (qtd in Wilson 39)

Ferrarotti means that even the private memory is constructed according to the social code. The individual is an integral part of the society, so private memory emerges from the position that the individual occupies in this society. It is the relationship and the communication output of the person with the social context. Describing the collective memory from sociological perspective, Ferrarotti notes:

[It is] a complex process that involves the individual and the context surrounding the individual. Memory is never a purely individual gift. Memory connects us along the chain of generations through language, usage, and customs, with both collective history and the history of those without history ... there is no memory that is not also an inter-and contextual reconstruct. (qtd in Wilson 41) Classifying memory into two categories, private and collective serves the aim of this paper. Memory connects the individual with the context, and the past with the present in inseparable links through the tools we use to preserve memory i.e. language usage, and customs, because these tools imply memory. Customs are preserved by remembrance and repetition through usage this is done by means of the language that plays a role in the transfer of such customs. For example, we learn/inherit our native language from ancestors who were linked to with the past.

Recently new areas of study have emerged that problematize the concept of memory, such as,' Micro-History/ History from below' and 'History from within' which fall under the umbrella of Memory Studies. To begin with, "Memory Studies' is an international and interdisciplinary field; it addresses the interplay of the past and present in sociocultural context. In other words, 'Memory Studies' is interested in the social form of individual memory." (Cofino) Memory Studies is an area of academic investigation, which is still relatively new. It started in 1925 and took its recent rebound in the 1980s. Memory Studies has three main sources that map their scholarly roots. In 'Memory: Concepts and Theory' Alan Cofino traces and summarizes the origins and ideas leading to the rise of the field of Memory Studies. Cofino refers to three leading figures who contributed to the establishment of the field of memory studies, the first is the French philosopher Maurice Halbwachs (18771945) who shed light on the individual memory and how it is reshaped by 
the social one. Halbwachs carved out this view in his 'Les Cardes Sociux de la Memoire' (translated into English as: On Collective Memory). Halbwachs' main contributions to the field of memory is his concept of memory as a process that has the characteristic of an ever-changing representation of the past. This definition has special relevance to the field of literature especially that of the narrative. To explain, as long as the process of remembering submits to continual change, then, we will continue to have different stories about the same period of past. And this process is the core of narration. Because narration is to recall the past experience coded in the attitudes towards this past. The second important figure in grounding the field of Memory Studies, particularly in 1932, was the British psychologist Frederick Bartlett (1886-1969). Bartlett showed that in the process of remembering, humans rely on summaries or schemes of the past, often adding and changing details. The third main person is the German scholar Aby Warburg, whose students of literature have intensively studied the medieval and early modern techniques that reflect Bartlett's views on memorizing (Cofino).

Moreover, discussing 'Memory Studies' and 'History from below,' few scholars, sociologists, and anthropologists pointed out to the notion 'history from within.' Chamberlain and Thompson explained that when conveying oral sources, they are obsessed with "an illusion of agency and an aura of authenticity," in such a case scholars/sociologists/anthropologist are, unconsciously, involved in "shaping the sources and framing the study." Some scholars claim to be "the conduit for...the raw, unadulterated voice of the 'other'." (16) Furthermore, Chamberlain and Thompson highlight the extent to which subjectivity prevails in oral sources and in history, sociology and anthropology. They state: "It is no longer history (or sociology, anthropology) 'from below', but history (or sociology) from within. The problem, however, is to unravel the complex layers of construction and meaning in the sources (16). Hence, anthropologists /sociologists/intellectuals/ writers or anyone investigating the past has a role in reading, interpreting and selecting the past for/in the present, consciously or unconsciously. In humanities, subjectivity is a primary feature, rather than a default. Consequently, memory in the literary text bears some traces of history, as well as fiction, is implied in the historical writings. It is factual fiction as well as fictional fact. This calls for an investigation of the text understudy by detecting the reasons beyond recalling, interpreting, selecting and revealing the past. My contention is to detect and reveal the urge for such recalling rather than investigating the reality or lack thereof in the selected text. 


\section{Hala Mahmoud Mohammad Harby}

Another term that came to be used as an equivalent to 'History from below' is that of 'micro-history'. Both of them bear the same meaning and concern of revealing history from the viewpoint of the ordinary people and the marginalised groups. What remains as an issue of investigation is the impact of Memory Studies on the emergence of micro-history. In his article, "On Micro-history", Giovanni Levi defines micro-historical approach as one that

[It]addresses the problem of how we gain access to knowledge of the past by means of various clues, signs and symptoms, ... a procedure which takes 'the particular' as its starting point and proceeds to identify its meaning in the light of its own specific context. (106)

Before the emergence of micro-history, our knowledge about the past was ascribed to the official records, the elite and the winners. Microhistory as an approach enables us to count for and rely on the concealed details, the other viewpoints, and the oral history apart from the official one. Micro-history is mainly concerned with the details of ordinary people in non-heroic states. Micro-history focuses on the particularity of the individual and tries no attempt to juxtapose individuals to shape a whole view. The idea of holistic, organic whole and generalization became out of date with the emergence of Memory Studies with its significant areas of history from below/ micro-history, and history from within. These areas highlight the significance of particularity and individuality.

Moreover, our era is characterized by the deconstruction of the centre, of postmodernism with its disconnection to the norm, and of course of post-colonialism with its notion of re-writing the self. In such an era Memory Studies with its reliance on oral, individual, unofficial sources becomes significant in our reading to literary works. Literary scholars are preoccupied with unravelling the meanings and the construction of narrative. Novelists, dramatists and poets are greatly informed and inspired by the richness of oral sources, whether in song or tradition, lore or memory. Thus, there is a blurred area between fiction and reality regarding historical events especially in Post-colonial contexts.

Unlike the inward version of memory in psychoanalysis, social/outward memory is of increasing interest in Post-colonial Studies. Post-coloniality attempts to interpret memory through its social context. Constantina Papoulias argues that "the currently emerging orthodoxy on the social production of memory abjures the orthodox psychological understanding of memory, only to substitute for it the imagined exchange of the well-governed city."(115) The mutual dependence, action, and 
impact between the private and the social are the issues of memory in "marketplace." A 'marketplace' is a term coined by the American anthropologist Clifford Geertz (1926-2006) in his masterpiece The Interpretation of Cultures (1973) in which he outlined culture as "a system of inherit conceptions expressed in symbolic forms by means of which men communicate, perpetuate, and develop their knowledge about attitudes towards life." (89) In his definition of culture, he adheres to "the inherit conceptions' that are expressed through symbolic forms. Memory is a social practice in the sense that

human thought is basically both social and public ... its natural habitat is the house yard, the marketplace and the town square. Thinking consists not of happenings in the head ... but of trafficking in ... significant symbols, words for the most part but also gestures, drawings, musical sounds, [and] mechanical devices. (Geertz 45)

Human thought is the product of the social interaction as in the marketplace. It submits to the- give- and -take process. Thinking is the result of social interaction through sharing, mutual symbols, words, gestures, or any other social codes. Human thought never happens in vacuum. It is precisely social. What settled among society as social code relies primarily on memory.

Memory here is the agent that links members of a society to their culture and collective past. Seeing memory as a marketplace depends on the mutual interaction and communication between the private and the public on the one hand and the past and the present on the other hand. This further highlights and ascertains that memory is a product of both the individual and his/her society as well as between the past and the present. Memory Studies reactivates the role of memory as having the ability to perform an action. To invite people to re-examine their past, for the present. Memory here points to the process by which people transform their past. It is in this sense that memory as stories of the marginal is, usually opposed to history. In this context, Geertz's marketplace does not simply configure the social nature of memory and its symbolic activity; it presents their production as a certain form of negotiation; "[memory] is a site of the transformation of norms." (Papoulias116) What the image of marketplace suggests is that memory cannot simply be a mere reproduction of ideological forms through corporeal habits; instead, memory is social to the extent that it functions as the theatre on which the past is brought back with all its norms.

To summarize, we have private/ individual memory as synonyms and public/ social/cultural/ collective as synonyms of historical memory. In psychoanalysis, private and social memories were treated as opposites, 


\section{Hala Mahmoud Mohammad Harby}

and private memory was viewed as the site of waste, because psychoanalysis separated the individual from his society, while for Memory Studies, private and social memories are considered as inseparable. One of Memory Studies' merits is the mixing of private and social memories, and the blending of the past with the present. More importantly to my supposition is that memory has the power to mix our old selves with our new ones. In his introduction to Halbwachs' book $O n$ Collective Memory, Lewis A. Coser concluded that Halbwachs was the first sociologist who stressed that our conceptions of the past are affected by the mental images we employ to solve present problems, so that collective memory is essentially a reconstruction of the past in the light of the present. Memory needs continuous feeding from collective sources sustained by social support. Truly, those who give an account of the past in terms of the present will generally be also aware that history is made of continuity as well as change. A moment of reflection suggests that, especially in periods of history that were well- documented, the present generation may rewrite history, but it does not write it on a blank page (Coser 34). It is this interplay of the past with the present that intrigued as well as urged the need for the present research. The whole issue seems interesting to the extent that the dwellers of our memory who witnessed the past became us in the present. As human beings we submit to forgetfulness, change and more importantly to the influence of imagination, these factors have the power to select, and give the past a new meaning.

Geertz's marketplace and Halbwachs' findings are of great significance to my supposition. The selected text: Soyinka's Death and the King's Horseman is a good example of Halbwachs' and Geertz's theories i.e. viewing memory as a collective social practice. In that sense memory attempts to re-write history in/ for the present. History, as well as the narrative, are made through memory in a way that the differences between them are blurred.

One example of the social collective memory is the genre of myth. Myth as a term has a wide range of meanings. According to Oxford Dictionary of Literary Terms, myth is a kind of primary narrative sequence, "normally traditional and anonymous," through which a given culture authorises its social customs for the origins of human and natural phenomena, usually in supernatural or boldly imaginative terms." (217) The meaning of the term 'myth' can be divided roughly into 'rationalist' and 'romantic' versions: 'rationalist myth' is a false or unreliable story or belief, (adjective: mythical) while 'romantic myth' is a superior natural mode of universal understanding (adjective: mythic). The romantic myth prevails in most literary contexts. Consequently, myths are regarded as: 
Fictional stories containing deeper truths, expressing collective attitudes to fundamental matters of life, death, divinity, and existence ... Myths have a mode of existence in oral transmission, re-telling, literary adaptation, and allusion. (Oxford Dictionary of Literary Terms 218)

Myth plays a major role in Africa; the formation of morality in Africa is rooted in tradition. It originates from gods and through the ancestors passes on to man. The great ancestors; the dead people of the tribe are the custodians of this tradition. Thus, one of the roles of myths is to bear the moral code of society. In such a case, god occupies the top of the hierarchy, while the ancestors are in the following position and finally humans are at the bottom. This conception is similar to the Elizabethan 'the Great Chain of Being'. In fact, man exists in a comprehensive world of myths, history and customs; Soyinka argues, in such a context, that the African world is unique. This world despite being unique has a common feature with other cultures: virtues of complementarity. "To ignore this simple route to a common humanity and peruse the alternative route of negation is, for whatever motives, an attempt to perpetuate the external subjugation of the black continent." (Soyinka, Myth xii) Soyinka admits the impact of myth and history on the Africans. History and myth give the black continent its features,

a fortunate blend of myth and history, penetrates even deeper into that area of man's cosmogonic hunger, one which leads him to the profounder forms of art as retrieval vehicles for, or assertive links with a lost sense of origin. (Soyinka, "Drama" 54)

This sense of origin, as Soyinka explained it, is "the coming -into-being of the race," (Soyinka, "Drama" 58). However, it is important to notice that this uniqueness and that blend do not negate the humanistic complementarity with other cultures. In other words, Soyinka is against the claim of the clash of civilizations. Truly, every culture has a unique character, but meanwhile cultures share the same humanistic principles.

Myth runs in Soyinka's works. Death and the King's Horseman (1975) is the most explicit exhibition of ritual. Soyinka utilises myth to "open collective unconsciousness" (Saudha 294) especially at that time in Nigeria's history after colonisation. Soyinka has written the play in a turmoil period full of coups, countercoups, and massacres. It is as critical scrutiny that: first, enables the Nigerian people to mirror themselves before colonialism. Second, it establishes a new principle of acting as one person in the face of the fragmentation caused by the coloniser. What gives myth such relevance is that traditional thought, according to Soyinka, operates in a cyclic conception of time which means the continuity among the dead, the living and the unborn (Soyinka, "Morality 


\section{Hala Mahmoud Mohammad Harby}

\& Aesthetics" 10). Myth in such a case bears the moral code of society, the principle of continuity inherent in myths of origin, secular or cosmic.

Soyinka aptly applies myth in different meanings. He sometimes uses it as mythology and (mythopoesis), and other times as mythography. Coupe defines "mythology" as the body of inherited myths. It is an important element of literature, and that literature is a means of extending mythology. 'A mythopoeic' means to create particular narratives that human beings consider as crucial to the understanding of the world. Thus, cultural and literary criticism may involve 'mythography' (Coupe 2). Mythography is myth-making, Don Cupitt concludes that 'myth-making' is a noticeably primitive and worldwide function of the human mind as it seeks "unified vision of the cosmic order, the social order, and the meaning of the individual's life." (Cupitt 29) Not only does Soyinka weave fables from myth, but he sometimes recites it as cosmic vision. In particular cases, he reshapes, or even distorts myth to serve his plan. In dealing with myth, it is of great significance to consider the selection of a specific myth and to bear in mind the pragmatic significance beyond it. For instance: Soyinka relies heavily on the myth of Ogun which goes through his works. Ogun is a rebel god who helped the humans with the artefact of iron and who dared pass the abyss. In recalling Ogun myth, Soyinka dramatizes the condition of modern Nigeria as it is a phase of transition and challenge to pass the dark phase after colonisation.

The African theatre represents such cultural element especially in its reliance on ritual as the moral code of society. Thus, theatre in Africa has a significant role in displaying traditional values, aesthetic matrix, rites, and beliefs. The African theatre is in a phase of transition where it has had deep roots in the past and at the same time adopts the modern devices and tools borrowed from western theatre. The myth is a central part of African theatre and culture. In an interview with James Gibbs (1981), Soyinka marks the significance of the theatre when he assures that "theatre is a more powerful force for social comment than other forms." (Soyinka 81) He validates the question in a play frequently being re-examined in the light of "new information, of new developments in society and of the increasing awareness of the participants in any play." (81) In societies where the level of interaction is greater "the theatre becomes very obviously a tool for social analysis." (Soyinka 81) Soyinka is a dramatist whose drama is that of existence; he utilises African myth in his drama, excavating African heritage to highlight a pre-colonial matrix of values embodied in myth.

In Nigeria, many historical and literary accounts suggest that myth has anchored the whole society in the past. Regardless of religious 
affliction, Nigeria is a multi-religious country: pagans, Muslims and Christians. Wole Soyinka, the playwright, novelist, poet, and political activist belongs to the Yoruba tribe in the south-western part of Nigeria. The Yoruba tribe pays tribute to a pantheon of a Supreme deity, Olorun, in addition to 400 minor gods who perform different tasks. Being a member of the Yoruba tribe, Soyinka portrays how the Yoruba culture has played an integral role in the process of acculturation which all African societies have experienced. In that regard, Abiola Irele argues that acculturation is a way of adaptation, and adjustment of the native culture with the colonizers. It is "the harmonization of two ways of life into a new entity." (45) It is a type of hybridity that asserts and takes pride rather than negates the pre-colonial period. Yoruba culture has been able to produce, as Irele argues "a stable institutional and spiritual groundwork for the transformation of collective life and feeling for the individual within this culture." (46) This is achieved through the utilising of myth as collective memory of the tribe where myth is not a mere tale, but a living fact. Soyinka, and other African writers, (such as the novelists: Chinua Achebe, Amos Tutuola, Flora Nwapa, and the poets: Okotp'Bitek, and Christopher Okigbo) attempt to work out a new spiritual coherence between their African heritage and their modern experience. Also, they attempt to link the individual with his society displaying the individual's social role as part of the balance of the world.

Soyinka is fully aware of the dilemma of his people and the fragmentations they have suffered. Douglas Gray defines "committed writer" as the one "who sees his work as necessarily serving a political or social programme or set of beliefs, and not merely aimed at achieving literary ends"(49) in this sense Soyinka has been preoccupied with his nation's socio-political issues. He is a political activist who shares the common concerns of Nigeria. He has suffered the experience of prison between August 1967 and October 1969. The Nigerian military authorities detained him without trial on suspicion of sympathy for the Biafra rebellion. His work The Man Died: Prison Notes of Wole Soyinka (1971) is written in memorial of his friend who died affecting by his wounds in prison. Another example of his commitment is his play The Madmen and Specialists (1970), which Soyinka has written during his imprisonment.

Soyinka's work presents myth as a comprehensive metaphor for modern life. Connecting his personal vision with the communal spirit of the tribe, Soyinka rediscovers the relationship between the communal spirit and the individual. The myth, as it develops in Soyinka's writings, depends on the notion of the artist role as mediator of the inner truths that 


\section{Hala Mahmoud Mohammad Harby}

bear the collective life, and on his task in renewing the essential values that govern this life. In Soyinka's writings we find a personal reinterpretation of Yoruba cosmology. He transports his vision or version of the myth, changing, adding, or even distorting it to make use of it within his artistic system. In the selected text, Death and the King's Horseman, Soyinka has presented a new variety of tragedy that deals with the theme of death trying to prove that death is not the end, but a stage of transition, and a metaphor for change.

One of the founding myths that shapes the Nigerian scheme of the legend is the myth of the chief man of the king. The myth is that when the king dies his horseman must kill himself in a ritual after a month of the king's death. The Yoruba people justify this death by the belief that the chief man must lead the king in the realm of heaven; otherwise, the balance of the world would be shaken.

Death and the King's Horseman (1975) derives directly from this myth as well as from significant historical events. Biodun Jeyifo argues that Soyinka dramatizes the famous incident in 1946

when the British colonial authorities were preventing the carrying out of customary ritual suicide by an important chief, a ritual suicide intended to officially conclude the funerary ceremonies for one of the most important indigenous rulers in colonial Nigeria; the Alafin of Oyo.

(Jeyifo121)

James Gibbs provides us with a lengthy description of the real incident that Death and the King's Horseman (hereafter $D \& K H$ ) based on; Gibbs assures that on Tuesday, $19^{\text {th }}$ December 1944, the Alafin of Oyo died after being in authority for 33 years. According to the Nigerian myth, Jinadu, the King's horseman would/ should follow his master by committing suicide. Three weeks later, the horseman came to the place of Oyo dressed in white and began dancing the dance of death in the street. At the critical moment, the British colonial officer prevented him from committing the ritual death but another shocking event occurred which was of the ritual death of the youngest son of the horseman (Gibbs, Wole Soyinka 118). ${ }^{1}$ Based on this real incident Soyinka created a play which combines Western and traditional elements. $D \& K H$ focuses on Elesin Oba, the King's horseman, who is preparing to die so that he can accompany the king who died a month earlier into the world of the ancestors. If the ritualistic death is performed, the royal will not be cast loose in aimless wandering. At the same time, the world of the living is also safe because the king's curses will not wrench the world from its 
regular course. However, the colonial district officer intervenes at the critical moment of Elesin's ritual death, describing the whole issue as barbaric. His action leads to the death of both Elesin Oba and his eldest son Olunde. The praise-singer's despair reflects the despair and anxiety of the whole tribe. He laments,

Elesin, we placed the reins of the world in your hand, yet you watched it plunge over the edge of the bitter precipice... you sat with folded arms while evil strangers tilted the world from its course. Our world is tumbling in the void of strangers.

$(D \& K H 75)$

By evil strangers the praise-singer means the British colonizer who has slopped the Nigerian world from its space.

The context of the play is concerned strictly with the functioning of different systems of law, European and indigenous. In this regard, the shadow of postcolonial Nigeria haunts the action on stage that concerns itself with colonial intervention. Thus, the play becomes about the spaces of difference produced when two versions of the law (tribal and colonial versions) confront each other. Every party wants to give superiority and priority to his rule.

Soyinka depicts the Western interference into his people's lives. Sergeant Amusa reported to the colonial district officer, Simon Piklings that "one prominent chief, namely Elesin Oba, is to commit death tonight as a result of native custom." ( $D \& K H 26)$ Amusa comments on this report "because this is criminal offence, I await further instruction." (D\&KH 26) The wife of the officer comments: "obviously he means murder." $(D \& K H$ 26) The way in which Pilkings' European viewpoint automatically interprets the nature of this event- transforming ritual sacrifice into a murder- is vital to the play's metaphysical investigation. Later in the play, the need for an effective and reliable investigation to sustain European power is confirmed when the local senior colonial officer tells Pilkings: "nose to the ground Pilkings, nose to the ground. If we let all these little things slip past us where would the empire be, eh?" ( $D \& K H 47)$ Elesin was arrested under the European claim to save his life before he could fulfil his ritual duty. Here, the claim is to protect Elesin from his barbarous action. Elesin's hesitation, in this regard, betrays the faith of the market-place women who earlier assured the local policeman Amusa that "tonight our husband and father will prove himself greater than the laws of strangers." ( $D \& K H$ 36) Moreover, Elesin is fully aware of the damage done by his failure to complete the ritual, telling Pilkings: "you did not save my life, District officer, you destroyed it." (D\&KH 62) This 


\section{Hala Mahmoud Mohammad Harby}

aptly sums up what Soyinka wants to expose. The colonial officer interferes in traditional tribal law to submit the native to his colonial order. However, Returning from England where he has studied medicine for four years, Elesin's son, Olunde completes the ritual in his father's place, sacrificing himself to ensure the continued spiritual wellbeing of his community. In the end, Elesin also kills himself using the chains with which he was shackled.

Olunde's sacrificing his life for the sake of his people's belief gives the end of the play such a vision; despite Olunde's experience of life in the West he still strongly believes in the relevance of his people's ritual. This tendency leads to interpreting Soyinka's vision in a particular way. It is not a clash of civilizations, despite having this view expressed by Elesin when he refers to the different culture as "law of strangers" (36), "ghostly one" (62), "those my spirit knew as enemies of my race" (63) "the white ghost entered, and all was defiled." (65) It is a matter of different realities. Soyinka himself rejected such interpretation-clash of civilizations- in his prelude to the play (D\&KH6-7).

Nigeria had obtained its independence from colonial Britain in 1960, and the play appeared in 1975. Bearing in mind that Soyinka is a political activist and a committed writer, one can establish a parallel transition between the incidents in the play and the political transition that occurred in the country. Soyinka depends on myth as collective memory as a means to gather his people around one unifying factor. It is myth that bears the moral code of the Nigerian society.

Soyinka's oeuvre can be summed up in three stages: the first phase contained his work in the late 1950s and the mid- 1960s. The second phase was during the 1970s. The third phase started in late1980s and 1990s. In the first phase, the critique of the romanticizing of African precolonial traditions and the African past is strong. In sharp contrast to this profile, the works of the second phase of the 1970s and 1980s witnessed Soyinka's immersion in the collective heritage of Nigeria, not out of his Nigritude, because he is always against this notion viewing it as ahistorical and artificial movement that never affected his life. As he gives evidence he asserts that tiger never needs to assert his tigertitude (Conversations with Wole Soyinka 10). He is always against the blind approval of Nigritude. He is a committed writer who is concerned humanistically with the dilemma of his nation. ${ }^{2}$

It is the second phase of Soyinka's production that is of relevance to this paper. In this phase, Soyinka's attentiveness to his native culture is clearly noticeable in his "Theatre in Traditional African Societies: Survival Patterns" in which Soyinka pays homage to the African traditions as main sources of his drama. What is extraordinary in this 
article is its point of departure. It departs from the orthodox "nationalist" method of affirming the survival of his traditional pre-colonial theatrical modes against colonialist negations of their legitimacy. Soyinka adopts the most challenging approach of investigating the emergence and development of modern West African theatre in the context of debatable dialectics of cultural suppression and nationalist resistance under the colonial rule (Soyinka, "Theatre" 4). In addition, Soyinka's Art, Dialogue, and Outrage (1993) one can easily detect his increasing sense of confidence in his African heritage in general and the Nigerian one in specific. In this work, Soyinka investigates the West African drama in which the Nigerian theatre represented a type of resistance, hybridity and passion. He argues: "We will conclude with the "new" theatre from which has proved the most durable; hybrid in its beginnings, the "folk opera" has become the most expressive language of theatre in West Africa." (Soyinka, Art 144) In an interview with James Gibbs, Soyinka defines the 'folk opera' as a kind of theatre that borrows from the masquerade tradition, but it started out from the church, seeing its parallel development to the development of miracle plays and mediaeval mystery plays (75). Another clear feature of the second phase is undermining the assumptions of the superiority of the Western culture. K.P. Sudha argues that Soyinka, among some other African writers, "mythicizes historical event and certain prominent figures to rediscover an authentic African heritage." (249) Soyinka tends to use the myth and folklore of precolonial Nigeria in an operatic form full of festival, rituals and African music. Thus, the returnee finally found out his way to his homeland.

Soyinka, the first African Nobel laureate in literature (1986), is a dramatist, an educator in the art of theatre, an actor, and a theatrical director. ${ }^{2}$ The Nobel Prize citation labelled his drama as one of existence. $\mathrm{He}$ uses this medium to oppose political, social and religious charlatanism. In the first phase, as Jeyifo states, his protagonists were passive towards the problems of their society. They produced mere diagnoses to the social problems, but with the second phase, Soyinka's drama witnessed a significant change directed towards solving these social problems. We find new anger and socio-political consciousness in Soyinka's works of the 1970s and 1980s (91). Death and the King's Horseman belongs to this phase of increased awareness and involvement in the public sphere. It is maybe a direct result of his experience of prison (1967-69), his return from Europe as a mature writer, and his realisation of the points of strength/weakness of his native-still living-culture in the post-colonial context.

One more issue we must put into consideration in studying Soyinka's drama is that Soyinka views that our external and the internal 


\section{Hala Mahmoud Mohammad Harby}

nature are inseparable. So, it is useful to be aware of his vision. Soyinka used memory to connect the present with the past and to connect the living with the ancestors. This synthesis is for one main target: to save the unborn; which means to protect the future. This shows Soyinka's unshakable belief in the Yoruba- worldview. In his book Art, Dialogue, and Outrage, Soyinka summarises his concept:

Man is grieved by a consciousness of loss of the central essence of his being and must indulge in symbolic transactions to recover the totality of being. Tragedy in Yoruba traditional drama is the anguish of this severance, the fragmentation of essence from self. (30)

Soyinka's view emerged from his realisation of the fragmentation of the European world in modernity, and the fragmentation Africa suffers in the post-colonial time. Returning to Africa and rediscovering its rich corpus of spiritual heritage, Soyinka utilised myth through recalling, evoking and empowering it to resist the fragmentation of the self. It is a result of the separation of the self from the rest of the universe. The ancestors to Soyinka and the Yoruba traditions are the source of law that controls the living. This notion of 'fragmentation of essence from the self' is of relevance for grasping the revolutionary and idealistic dimensions of making myth in Soyinka's drama. Thus, myth in Soyinka's drama reunites the self with the universe, connecting the present with the past as well as the future.

In a parallel mode Soyinka displays five finely juxtaposed scenes to assert that his people are equal to the colonizer. By resorting to a myth that is shared by all Nigerians, Soyinka is able to prove that his people are a nation with collective memory. In the prelude of the play he recommends that "the play should run without interval." (D\&KH 8)

In the beginning of the play, Elesin Oba says, "memory is master of death" $(D \& K H 20)$. It is to assure the author's intent to focus on collective memory as the main shared aspect of life among Nigerian people after British colonisation. It also confirms that without memory there is only death. Thus, Elesin functions as a reminder to Nigerians that it was collective memory that unified them in the face of colonisation and the fragmentation that followed. The order of the scenes validates this interpretation. The play consists of five scenes: where the first four scenes alternate between the African and the Western, the last scene fuses both Western and African existence. This sequence asserts Soyinka's intention to put his people in an equal position to the colonizer and his plan to make the native law prevails in the end of the play.

The first scene opens in the market. Women are carrying their baskets while Elesin Oba enters followed by the drummers and a praise- 
singer. The principal role of the praise-singer is that he jests, praises, and warns in traditional wisdom that runs through the collective memory of the tribe. The praise-singer is the person who gives the reader the first key to the tragic flaw of the protagonist. He warns Elesin of the weakening effects of women. He says: "they love to spoil you but be aware, the hands of women also weaken the unwary." (D\&KH 10) The dialogue between the praise-singer and Elesin is significant, especially the song of 'Not-I-Bird'. This song/dialogue has a metaphysical tone which reflects the preoccupation of Elesin at that moment of transition with the spiritual abyss, and the realm of the ancestors. In this song, Elesin assures that he is facing death for the benefit of the whole tribe and the balance of their universe. The praise-singer commends Elesin: "in your time we do not doubt the peace of the farmstead and home, the peace of road and hearth, we do not doubt the peace of the forest." ( $D \& K H$ 13) As Dan S. Izevbaye observes, the 'Not -I- Bird' breaks the dance to warn Elesin. The song "exposes his alienation from his world." Izevbaye argues, although Elesin clarifies that the 'Not-I- Bird' refers to the fear of death, it also "ironically implies an anathema since it is the act of warding off evil by snapping the fingers around the head" (Izevbaye 121).

To encourage Elesin and remind him of the significance of his ritual sacrifice, the praise-singer draws on 'the past' of their people and recalls the memory of how the white slavers caused wars and took away the heart of their race. "The city fell and was rebuilt, the city fell, and our people trudged through mountain and forest to find a new home, but . . .our world was never wrenched from its course." ( $D \& K H 10)$ To that Elesin answers: "the gods have said No" (11) The praise-singer then asks Elesin: "If that world leaves its course and smashes on boulders of the great void, whose world will give us shelter?" (D\&KH11) The praisesinger asks Elesin to ponder if Elesin is fully aware of his sacred duty to preserve the order of their world. Elesin confirms his awareness and his readiness to sacrifice himself and join their ancestors. In the past, according to the play, the coloniser destroyed Nigerian homes but could not destroy their souls or their beliefs; collective memory as represented in the ritual of the horseman death gathered Elesin with the praise-singer and their people where all abide by their ancestors' law. There is a shared consent among Elsein, the praise-singer, and the rest of the women of the market on what Elesin is going to do for the tribe. The existence of the white colonizer is temporal, and this existence does not have the slightest effect on the tribe as long as the whole tribe still holds on to the past with all its beliefs, fears, and hopes. In short, they are safe as long as they are still connected to their past. Memory here is Soyinka's strongest weapon 


\section{Hala Mahmoud Mohammad Harby}

which defies the white man or the ghostly one as Elesin keeps calling the colonizers throughout the play $(D \& K H 62,63,65)$.

The second scene is Western; we see Simon Pilkings, the district officer with his wife, Jane. They were wearing some fancy clothes and were dancing in an event, which later we learn was the 'egungun' masquerade; the masquerade of Nigerian myth of death. The scene takes place when sergeant Amusa refuses to talk to the Pilkings because the costumes they were wearing are those of the dead who must be respected. Amusa being a Muslim is expected not to believe in such African 'pagan' myth. His refusal to talk in the presence of the mask suggests that even though he is a Muslim, his African roots and his connection to his people's myths and heritage mark the collective element in the play. Refusing to speak, Amusa writes a note that there is an emergency where "one prominent chief, namely, the Elesin Oba, is to commit death tonight as a result of native custom. Because this is a criminal offence, I await further instruction at charge office." $(D \& K H 26)$

Pilkings' home servant, Joseph is a Christian. Pilkings asked Joseph if the custom has any effect on him, Joseph answers: "a good Christian and white" cannot be affected by the custom that he describes as powerless. When Jane Pilkings asks Joseph about the meaning of the beatings of the drums that she hears, Joseph explains that they send two messages: "the death of a great chief and then, it sounds like the wedding of a great chief" (D\&KH 30). The same scene informs the audience that Simon Pilkings has sent Olunde, Elesin's son, to England to study medicine against his father's will. The result is that there is already tension between the Pilkings and Elesins. Moreover, Pilkings again interferes in Elesin's affairs by trying to stop Elesin's ritual death. Simon Pilkings is urged to behave as such for such irrational belief never takes place in the presence of the white man, second is that the prince of England is on a trip to the colonies and he is now in town. It is a disgrace that the prince may hear about such deeds taking place under the flag of the empire.

The second scene is very significant to the whole play. In this scene, Soyinka draws the English coloniser as a selfish, and an arrogant creature who is concerned with nobody but himself and his prince. Soyinka depicts the Muslim as an African first. Amusa keeps silent in the presence of the 'egungun' mask, Soyinka thus tends to credit his people. Despite their defects, Soyinka portrays the Nigerians as people who strive to maintain their traditional system of order and harmony.

The third scene shifts again to the marketplace. Amusa and two policemen have come to arrest Elesin. The women of the market tease and scorn Amusa. Elesin leaves his bride and begins the dance of death. 
$\mathrm{He}$ is expected to travel to the other side of the world, to death, to join the king who died a month ago. Iyaloja appreciates his journey. In the third scene, Nigerians refusal of the white man's existence is evident. The women of the market attack Amusa and the two constables and scorn the Western way they dress, and their blind submissiveness to the white man.

In juxtaposition to African scenes, the fourth scene is Western. It occurs in the ball where the prince of England honours the party with his attendance. A police brass band that has white members only, plays Rule Britannia incompetently (as Soyinka illustrates in the fourth scene) as the prince enters the ball. In this part, Soyinka portrays the contradictory situation between the whites and the Africans. The white men do not play harmoniously or in accordance with each other while Africans achieve such unison and harmony in their drumming. For Soyinka, this signifies the Africans belief and agreement on the significance of their rituals; Geertz's 'memory as marketplace' is applicable here. A dialogue between Olunde and Jane Pilkings about the difference between British and Nigerian worldview is analysed in detail later.

In the fifth and final scene, Elesin is in prison in a wide iron-barred gate that was used in the past as a cage for African slaves before being transported to the new world by the white slavers. In a dialogue with Pilkings, Elesin tries to explain the damage he (Pilkings) has already caused to the rest of the people by his interference in the rituals. Elesin now is unable to perform his duty and maintain the harmony in his society. It is another scene which implies the tension between African people and the white man. Also, this scene indicates that Nigerian people not only recall their shared myths as one expression of collective memory but Nigerians belief in their myths urges them to act accordingly. The play ends with Olunde, Elesin's son, sacrificing his life to save the tribe and to give balance and peace to them all. In his return and after feeling ashamed of his procrastination, Elesin kills himself with the iron chain of the prison. Thus, Elesin sets himself free from both the colonisers' rule and the first life, and now he is on his journey to the other world, that of the ancestors.

The five scenes of the play juxtapose two civilisations, two systems of law, and two persons committing suicide for the sake of achieving the common law of the tribe.

In "The Fourth Stage" Soyinka formulates his dramatic Theory of Ritual. First, he defines tragedy in relation to cultural and private experience as "the most insistent voice that bids us [to] return to our sources." (140) It emerges from man's realisation of "certain areas of depth-experience which are not satisfactorily explained by general aesthetic theories; and of all subjective unease that is aroused by man's 


\section{Hala Mahmoud Mohammad Harby}

creative insights, that wrench within the human psyche." (Soyinka, "The Fourth Stage" 140) Tragedy in Yoruba drama reveals the suffering of this division, the fragmentation of essence from self. Soyinka explains that it is the first fragmentation of Orisanla, the primal deity, from whom the entire Yoruba pantheon was born. ("The Fourth Stage"152). Yoruba pantheon in such a way suggests that the fragmentation Yoruba suffers, can be reconciled through gathering around myth, and through reminding recent people of their origin. Drama, according to Soyinka, has a reconciliatory role in society.

Soyinka selects two primal hero-gods for his theory: Obatala and Ogun. According to Soyinka, gods were once entirely separated from human beings, and many efforts were made to cross the gulfs between the deities and humans. Ogun was the first to succeed in extracting iron from the earth, and he was the first to enter the abyss between deities and humans, providing the human world with the sources of its weapons and tools. Soyinka describes Ogun as the paradigm of ritual archetype "the transitional yet inchoate matrix of death and becoming." ("The Fourth Stage" 142) Ogun is the god who exposed the risks of the abyss and created a road from the deities to the human world so, he is seen as the deity of the road in addition to being the god of iron and war.

In his article "The Fourth Stage" Soyinka makes the continuum among the unborn, the living, and the dead possible through the notion he coins, "the fourth stage," a world that links the living with their ancestors and with the future on the one hand and links the man with the deities on the other hand. It is the self-awareness that Soyinka intends to follow through these realms. Transition through the abyss of the unknown realm is a metaphor for the phase modern Nigeria passes through. In the four plays that contain this notion of transition, Soyinka focuses on the consciousness and self-apprehension of the protagonists. The metaphysical dimension in Ogun's myth is the key to understand Soyinka's work. 'Transition' as a notion runs through Soyinka's works in all phases of his works. What is unique about this transition is that it indicates the moral content of Soyinka's drama; it is the metaphysical dimension, based on his interpretation of the Yoruba myth. Transition assumes a continuum between the realms of the unborn, the living, and the dead. Soyinka is concerned with defining the experience of drama concerning ritual, which he views as "its historical and most frequent contemporaneous source." (Davis 149) However, Soyinka is equally concerned with defining the experience of drama in relationship to revolutionary social awareness. He is concerned with the relationship of the individual within the community, and with the relationship that links drama, ritual, and contemporary society. Soyinka explains in "Drama and 
Revolutionary Ideal" the meaning of community emerging from the ontological supposition of Yoruba metaphysics. It suggests three major areas of existence: the world of the living, the world of the unborn and the world of the dead, and a fourth mediatory world which Soyinka adds, and calls the area of transition. He defines it as "the chthonic realm, the area of the really dark forces, the really dark spirits, and it is also the area of stress of the human will." (89) This supposition assumes that the individual must disintegrate from his individuality and dare to enter the unknown abyss to examine his will. It is a matter of reintegration of the self with the universe. The significance of this ontology becomes apparent in Soyinka's discussion of Ogun's rites in "The Fourth Stage." Ogun as Soyinka portrays, is the incarnation of will and the ability to change the status quo. Soyinka presents $O g u n$ as a god

[who] has undergone the experience of disintegration, whose spirit has tested, and psychic resources laid under stress by the most opposing forces to the individual assertion, only he can be the force of fusion between the two contradictions. The resulting sensibility is also the sensibility of the artist, and he is an artist to the degree that he comprehends and expresses the principle of destruction and recreation. ("The Fourth Stage" 150)

Ogun then has two contradictory forces: the courage and ability to disintegrate and reintegrate, to destruct and construct, to destroy and rebuild, to bridge the abyss and to communicate with the ancestors. He has the ability to combine two contradictory forces, life and death; in other words, it is the power of hybridity. To express such tension needs a sensitive artist, who has a panoramic view to the whole image, circumstances, and context, the resulting ability of this view is the ability of destruction and recreation. Unlike Obatala who received suffering and confinement passively and patiently, Ogun dares to act, to change his circumstance, even if it means facing death and passing the dark, anonymous abyss. The myth of Ogun is repeated through Soyinka's fictional works, and is explained in his critical essays.

Applying this theory to Death and the King's Horseman, we find that Elsein Oba's duty is to bridge the abyss of transition to exist with the ancestors, and to have the ability to disintegrate from the self in order to re-integrate in the fourth stage. It is the struggle of the will under stress to perform an act. Examining the will under stress is the core of Soyinka's theory of transition, and the reason beyond Soyinka's interest in the myth of Ogun. For Soyinka, Ogun is the embodiment of the free will. Soyinka asserts that "nothing but the will . . . rescues being from annihilation within the abyss." ("The Fourth Stage"150) This theory of ritual and transition clarifies Soyinka's vision of the social role of theatre. 


\section{Hala Mahmoud Mohammad Harby}

Soyinka is an advocate of the role of theatre as a precursor of social change. In an interview with Soyinka he expresses his firm belief that "any work of art which opens out the horizons of human mind, the human intellect is by very nature a face for change, a medium for change." (Conversations with Soyinka 27) In the African context, drama cannot be discussed without linking it to notion of ritual. This is no more obvious than in postcolonial plays in which ritual manifests its self in one of two forms. First, and as K.P. Sudha explains, ritual structures the action within the performance; it is a significant agent and reinforces the sense of community on stage and in turn the sense of community in the audience. In second way in which ritual is used and introduced in postcolonial plays is that of ritual as an expression of hybridisation. In both cases, the ritual is utilised to satisfy social and political thrust which needs a positive response from the audience (Sudha 244-249). Both categories of traditional drama along with Soyinka's dramatic theory shape Soyinka's literary production. Disassembling the fusion of these elements helps to understand Soyinka's dramaturgy.

The traditional drama has represented the universal need for repair and renewal mainly through two theatrical categories. First, by reestablishing to the mechanism of satire and comedy second, by returning to rites and rituals, as Sudha argues: "The first is an attempt to diagnose what is wrong with a society and the second is a step to set it right by rehashing and strengthening the conventions." (Sudha 251) Soyinka's plays can be divided based on such categorization. The first group of plays employs the dramatic resources of the popular stage like masquerade and caricature aiming at "the exorcism of collective pain on a purely sociological level." (Sudha 251) In Kongi's Harvest, the Jero plays are among other works that belong to this category. The second group is metaphysical in their techniques and content. They are "ritualistic in structure and tragic in tone" (Sudha 251). Death and the King's Horseman strongly embodies the second type. It exorcises the collective African faith as a way of diagnosing African pain; it is concerned with the metaphysical, taking rituals and myth as its structure and agency for one target: social change.

In the same vein, in the Yoruba cultural setup, there is a connection between one and another of the living, the dead and the unborn. Soyinka employs many native myths as the basis of his people's collective memory. Dealing with the theme of death, one of the central myths that Soyinka relied on is the myth of 'chameleon and lizard.' ${ }^{3}$ This myth implies that death is hidden in the speed of lizard while life lies in the slowness of chameleon. 
Soyinka traverses both the actual event which the play based on and the myth of 'chameleon and lizard'. First, in the actual text, the son of the devoted for death was a trader in Ghana. However, Soyinka made him a student of medicine in Britain. Such a change draws the British colonisation into his text in a planned manner. Olunde, the son of Elesin came from Britain and committed suicide for the peace of his people. Such a change adds richness and vitality to the play. It turned the play from mere representation of a myth to an ambivalent relationship between pre-colonial and post-colonial Nigeria on one side and between Nigeria and British colonialism on the other side. Second is that Soyinka reverses the meaning of 'chameleon and lizard' myth. According to the myth, slowness is praised, and it connotes life, while speed is damned as it connotes death. Soyinka damned the slowness of Elesin, while he praised the speed of Olunde. Iyaloja describes the location of both Elesin and Olunde after their death:

$\mathrm{He}$ [Elesin] is gone at last into the passage but oh, how late it all is. His son will feast on the meat and throw him bones. The passage is clogged with dropping from the king's stallions; he will arrive all stained in dung ( $D \& K H 76)$.

Soyinka uses the myth to juxtapose two scenes and to stress the significance of obeying ancestors' law. In such a scene, speed is of crucial importance while being slow is a sin. In an interview with Valerie Wilmer, Soyinka asserts that when he uses myth, he bends it to his own requirements, because he does not believe in "carbon-copies" in any art form. Soyinka declares that "you have to select what you want from traditional sources and distort it if necessary." (4) Even if Soyinka reversed it, myth is still a source of power that gathers Nigerians around their collective memory. It achieves many purposes: it gathers Nigerians around one target when colonisation and different languages separate them. It gathers people around one unifying issue: the past. Soyinka anchors his characters in a real situation. He purposefully gives his characters a memory. The play with its incidents and dependence on actual events as well as known myths ascribes to collective memory, to the essential premise of a character's past deeds and thoughts, from which we can understand present attitudes. The past represented in myth is the medium of resistance Soyinka invented in his play. Myth, thus, is a monster-like creature that Soyinka awakens to face the secular, individualist culture of British colonisation. Soyinka resists not only through his belief in the connection of all elements of the universe, but also through his coinage of 'the fourth stage' of transition where the will is the agent to perform an act, and to choose the road to tread. 


\section{Hala Mahmoud Mohammad Harby}

As aforesaid, the myth of Ogun goes through Soyinka's works. In Death and the king's Horseman the concept of 'the road' is an essential concept that gives the play its richness, and vitality. It is the journey of life that ties the ancestors to the living and the unborn. The transition is the fourth stage of the road. In other words, Soyinka puts Nigeria on the road of will for the aim of continuity, where speed is a must, and slowness is a sin.

In a conversation with Jane Wilkinson, Soyinka postulates that there is a meeting point within the collective memory of humanity, within the mythologizing attitude and inclinations of humanity. As for the recurrent myth of Ogun and his archetypal journey into the abyss, Soyinka asserts that Ogun is "a recognition of a continuing. A real aspect of the creative and social instinct of my own society." (156) The myth of Ogun or the rebel god was reinforced by Soyinka's discovery of parallel examples in his studies of other societies such as the Greek god Prometheus, and Sumerian semi-divine Gilgamesh. "It is a question of complementarity" (156). However, the primary purpose of all these parallels is to glorify Africa; Soyinka resorts to myth, rituals, and festivals to assert the specific nature of his art that emerged from the black continent. It is his way to confront the existence of the white man in Africa.

. In his writing, the most primitive African ritual forms and idioms, stand side by side with a view of ritual as universal, emancipatory and even revolutionary. This attitude raised a question of the author's awareness of his historical context; it also increased the claim of his commitment to his society. The issue goes far beyond the clash of civilizations. Soyinka chooses to act on his native team, where myth is not just a tale, but an allegory and a paradigm that gives clear answers to the ambiguous questions about the universe. In an interview with Henry Louis Gates, Jr. 1975 Soyinka asserts that it is misconception to suggest that the principle of self-sacrifice is alien to African traditional societies. He elaborates that there is one principle, one essential morality of Africa society that "it is the totality that is important" (59) Soyinka could recall the collective memory of Nigeria and collect Yoruba people around one source of knowledge that came from the ancestors; consequently, this way became a tool of ignoring the coloniser as a type of resistance. Soyinka made the myth as the reality of his people, utilising it to assert their unique nature. In this regard Franz Fanon portrays the same meaning in his book The Wretched of the Earth, he illustrates: "colonisation was a denial of all culture, history and value outside the coloniser's frame, in short, it is a systematic negation of the other person." (Fanon 200) 
Memory stands for the continuity of the whole society in opposition to western negation of the others.

In Death and the King's Horseman, Soyinka juxtaposes European and indigenous laws in a way that he shows how Western interference into his people's life was destructive. An extended dialogue between Olunde, the medical student and the wife of the white district officer Jane Pilkings reveals Soyinka's views about the ambivalent relationship between Nigeria and Britain and holds a compelling comparison between both cultures in the matter of individual sacrifice for the sake of the nation. This dialogue is relevant in the sense that it validates the Nigerian collective memory as the source of law. Olunde goes to the fancy ball to search for the district officer. He finds Jane, the officer's wife, wearing a masquerade of egungun. She gives an excuse for wearing the masquerade because his highness is meeting her in person. Olunde replied through a question: "And that is the good cause for which you desecrate an ancestral mask?" (D\&KH 50) As such, Soyinka portrays the white people as people who do not respect others like using sacred masks of death in a fancy party to please their prince. Also using the word 'desecrate' indicates that Soyinka accuses the white people of ignorance. They do not know the purpose of this mask. It is for a ritual of death, an event which bears sacred significance and not just an attire for entertainment in a fancy ball. Evidently, Olunde does not exonerate the white race of two issues: ignorance, and insulting others. Using the masquerade in a fancy party is not his only evidence, yet, Olunde admired their courage in this 'war' which he sees as an act of sacrifice $(D \& K H$ 50). By 'the war' Soyinka means World War II (1939-45). It is one among other reasons that Soyinka decides to tell the story two years earlier than the actual story, merely to be concurrent with the war. For the same reason, he turns the son of the real chief from just a trader in Ghana to a student of medicine in England. These among other changes are Soyinka's plot to introduce the white men in his play and to display colonialism from different façades.

Thus, Olunde turns the speech to the recent war England is involved in asserting how one of the English soldiers decides to scarify his life to save others when he deliberately bombs a ship to protect other ships. In his way to convince her of the significance of the ritual of death his father about to achieve he said that he found the deed of the British soldier "rather inspiring. It is an affirmative commentary on life ... that captain's self-sacrifice." (D\&KH 51)

Jane's answer is representative of her materialistic culture; she affirms: "Nonsense. Life should never be thrown deliberately away." (52) Jane is a Christian woman, and her answer implies a contradiction to 


\section{Hala Mahmoud Mohammad Harby}

Christianity because Jesus made the ultimate sacrifice. In Christianity, Jesus sacrifices himself to pay for every human being's sin, because of this sacrifice Christians reconciled with God. Jesus crucifixion about 2000 years ago was essential to God's plan of redemption and salvation. Isaiah 53:5 concludes "the chastisement for our peace was upon Him, and by His stripes, we are healed." (Isaiah 53:5) Thus, in Christianity, selfsacrifice is an essential principle for salvation.

Soyinka juxtaposes two scenes: the first is the Christian's deviation of the principle of self- sacrifice, second; Nigerians' belief in their rituals and ancestors' law. The issue here is about the power of collective memory. British accused the Nigerians of being barbaric because they preserve their collective memory and act according to its tenets. Jane expected Olunde, with his degree in science and his four-year living in England, to have assimilated to the British world rather than to his native barbaric culture. Jane, convincingly, declares that her husband is going to stop Olunde's father's ritual death. Olunde confidently answers:

He [Simon Plikings] is wasting his time ... I don't want him to incur the enmity of our people. I came home to bury my father . . . how can I make you understand? No one can undertake what he does tonight without the most profound protection the mind can conceive. What can you offer him in place of his peace of mind, in place of the honour and veneration of his people? ( $D \& K H 53)$

Olunde speaks decisively and confidently. What his father undertakes is necessary for the peace of mind, for the honour, and the respect of his people. Olunde thinks that the district officer is wasting his time because the ritual is their ancestors' heritage, their religion. Trying to calm the tension between her and Olunde, Jane hints that it is not just medicine Olunde studied in England. Olunde seriously answers "yet another error into which your people fall. You believe that everything which appears to make sense was learnt from you." ( $D \& K H$ 52) Jane affirms that Olunde has learned to argue, in another hint that he has learnt the art of speech and argument from British people, but according to her opinion, his argument does not make sense, despite his cleverness in putting it. She declares her opinion on the whole case of his father: "it is still a barbaric custom. It is even worse-it's feudal! The king dies, and a chieftain must be buried with him, how feudalistic can you get!" (53) In his turn Olunde similarly criticises white people pointing out to how the white people are "bowing and curtseying the dancing prince when his highness passes." (53) Olunde ironically says that this is happening "even in the midst of a devastating war, look at that. What name would you give to that?" (D\&KH53). Jane answers that it is a therapy according to British 
understanding. She confirms it is "the preservation of sanity in the midst of chaos." (D\&KH 53)

The above conversation between Olunde and Jane highlights that naming is crucial in any discussion, while Jane sees dancing as sanity Olunde declares that he also has the right to name her people (like she names his) and describes what he had seen in the ball as decadence. Moreover, he uses the term primitive in reference to white man's actions in the war in a manner that subverts Jane's - as well as the West- use of the word in reference to the Africans. Olunde views the devastating war among the white nations as 'primitivism'; he concludes:

You white races know how to survive ... By all logical and natural laws, this war should end with all the white races wiping out one another, wiping out their so-called civilisation for all time and reverting to a state of primitivism the like of which has so far only existed in your imagination when you thought of us . . . your greatest art is the art of survival. But at least have the humility to let others survive in their way. $(D \& K H 53)$

Survival according to Nigerian cosmology occurs when one sacrifices himself for the sake of all; it is the community before the individual in contrast to the individualistic nature of the colonizer. Olunde ironically asks her and her race to have the modesty to let his people survive in their way. The balance of the universe depends precisely on the 'fourth stage of transition' which Elesin is devoted to achieving by his ritualistic death. This stage preserves the continuum of the other three stages: the unborn, the living, and the ancestors; it is the way Olunde's /Soyinka's people view the world. Jane asks Olunde: Is this your way to view the world "through ritual suicide?" (D\&KH 54) Olunde again criticises her race and the mass suicide that young soldiers are obliged to experience in a mad war. He asks:

Is that worse than mass suicide? Mrs Pilkings, what do you call what those young men are sent to do by their generals in this war? Of course, you have also mastered the art of calling things by names which don't remotely describe them. ( $D \& K H 54)$

Olunde aptly touches on the shortcomings of the white race, which is "calling things by names which remotely describe them".

Soyinka puts a significant description of this case as an art. Soyinka uses the word 'art, satirically because in its essence art must have rules, laws, leaders, and avant-gardes. Olunde describes white people as masters of not only this art of naming the others but of forging facts as well. He says:

In your newsreels, I heard defeats, thorough, murderous defeats described as strategic victories . . . - hordes of your wounded 


\section{Hala Mahmoud Mohammad Harby}

passed through those wards. I spent long evenings by their bedside while they spoke terrible truths of the realities of that war. I know how history is made ( $D \& K H 54)$

Here, Soyinka is practising Thompson's notion 'history from below,' he focused on the ordinary people and little-ranked soldiers in the World War II. He draws their suffering apart from the claim of the news report that described the case as 'a strategic victory'. Olunde not only represents his Nigerian pagan culture but he represents Soyinka as well. Both of Soyinka and Olunde are crossroads men; both have experienced living in England, both returned to the motherland, also both tend to believe in their native beliefs rather than the claim of illumination that England raises in the face of the black continent. To follow up Olunde's viewpoint is to portray Soyinka's point of view of the British colonisation and its aftermath upon his people.

Some critics and scholars shed light on the play as a type of clash of civilizations; however, in his note on the play to be performed on the stage, Soyinka asserts that he finds it necessary "to caution the would-be producer of this play against a sadly familiar reductionist tendency, and to direct his vision instead to the far more difficult and riskier task of eliciting the play's threnodic essence." ( $D \& K H$ Author's Note 6-7") It is about the spiritual life and cosmic worldview in Yoruba tribe. In other words, Soyinka defines Yoruba tribe through its collective memory. If we accept the clash of civilization-interpretation, then we accept the definition of Africa as presented by the European culture; we would then use the European way of perception as a reference. It goes without saying that this is the remotest interpretation that Soyinka would intend to his play. Soyinka's culture connects man with his universe in a harmonic tone where the unborn, the living, and the dead are tightly connected thanks to the fourth stage of transition, in which the devoted person is responsible for the balance of the world.

So, the play goes far beyond the clash of civilizations. It is about the metaphysical, and spiritual world and essence of the Yoruba tribe. As for the colonial factor, Soyinka asserts that it is an incident, a catalytic incident merely for the sake of dramaturgy (" $D \& K H$ Author's Note 7"). Excavating the collective memory of his people Soyinka re-establishes a new version/vision of his country, maybe first, to discover, then, to recuperate it from the deep wound of colonisation.

\section{Conclusion}

Soyinka utilises myth as the collective memory of his people. He uses myth as a medium to unify the fragments of society caused by the colonization. Transition is the deep concern in this play, where Ogun is Soyinka's patron god. The transition of the abyss is Soyinka's emblem 
that is repeatedly used. It is a metaphor for social change, especially the stage of transition, which is in process, in postcolonial Nigeria. It is the core of Soyinka's philosophy: the call for change, or more accurately the ability for change; -an ability the first to eliminate by the interference of colonialism. Through the play Soyinka could portray a new national identity based on the deep roots of myth. Thus through myth, Soyinka could unify what the colonisation had shattered.

The ancestors, living generations, and the unborn citizens of the world co-exist in the ways that the victories, defeats, energies and capacities of precolonial and colonial pasts still exist in the postcolonial present and future, just as structures of feeling, or, in other words as layers. These worlds cannot be merged without the fourth stage of transition. The transition can be obtained only in the presence of the free will of man. In other words, what we do in the present can reclaim the past and preserve the future.

The significance of Death and the King 's Horseman lies in the fact that it is the first attempt of Soyinka on the theme of decolonisation. For a long time, Soyinka was preoccupied with the West's disruptive effect on Africa in general and on Nigeria in particular, but through this play, Soyinka asserts that colonialist intervention has failed to destroy the traditional culture, rituals, art, and memory of precolonial Nigeria. The theatre is his tool to assure the authenticity and, more importantly, the durability of his culture. The latest theories of memory, 'memory as a marketplace' is aptly applied in Death and the King 's Horseman. It is not strange that the opening scene of the play is in the 'marketplace', where all agree on the same rules which preserve the universe; all agree on their resentment of the white man, and all believe that Elesin is devoted to a great role. The marketplace unifies all citizens of Yoruba tribe as they have same past, with the same collective memory and the same respect to this past. To put it differently, the idea of transition strongly links the past with the present and future. Soyinka adheres to the collective memory through myth to produce a constant Nigeria, where the white man's existence is just a ghost-like as Elesin expresses this idea in the play and as Iyaloja describes the colonisers as strangers. Collective memory embodied in the myth and rituals gathers the whole tribe against the law of the coloniser/stranger.

Soyinka confronts the West with a different reality of his people. He pushes the issue a little further. Answering to Gatyri Spivak's question: Can the subaltern speak? The conclusion of this play answers: yes. The subaltern cannot only speak, but he can bravely and loudly speak and face the colonisers, even if this confrontation leads to committing death. The ritual death is, in fact, the continuum of the other stages of life 


\section{Hala Mahmoud Mohammad Harby}

to the whole tribe who believes in life as an integration of different elements: the living, the dead, the unborn and the transitional stage that links the first three elements - a viewpoint that deviates the secular, egocentric vision of life in the West.

\section{Notes:}

1-Jeyifo cited this event as happening in 1944, while Gibbs mentioned it happened in 1946, what concerns this research is the event itself rather than its date.

2- Oluwole Akinwande Soyinka was born on 13th July 1934 in Ijebu Isara. Soyinka was brought up, educated and worked in the western region of Nigeria and in Lagos. Soyinka went to University College Ibadan, an institution affiliated to the University of London. Soyinka belongs to the "Titans" a generation of Nigerian literary intelligentsia whose leading figures are Chinua Achebe, J.P. Clark, Christopher Okigbo and Soyinka himself. In the 1960s, the first decade of post-independence period in Africa, Soyinka emerged as the "enfant terrible" of the then "new" postcolonial African literature, his targets and adversaries including not only corrupt officials and politicians but also writers and critics (Wole Soyinka: Politics, Poetics \&Post colonialism xvi:1). From the very beginning, Soyinka has been a political activist and a committed writer in the African anti-colonial struggles. According to Biodun Jeyifo, two issues marked Soyinka's unique location in 'Titan group': first, there was "the extraordinary versatility and prodigiousness in all the literary forms and genres" (Wole Soyinka: Politics, Poetics, \& Post colonialism 5). As for his 'versatility' which means his adaptability and flexibility he gained this characteristic from his teaching drama in universities of Oxford, Harvard, Yale, Nevada, Las Vegas, acting and working in English theatre where he used to adapt English classics such as Euripides, Shakespeare, and so on, to the Royal Court theatre in England. This versatility provided him with a sense of communication with spectators, and flexibility to achieve his target in various ways. As for 'prodigiousness', he is the first in Titans group whose canon contains an enormous amount of plays, novels, and nonfictional writings in sociopolitical aspects, and literary criticism. Jeyifo elaborates, Soyinka occupies his distinct place within this group on account of his tendency for taking very daring artistic/political risks in persistence on his deepest political and ethical beliefs. The combination between the artistic and political hazards is "one of the most charming rather complex aspects of Soyinka's career" (Wole Soyinka: Politics, Poetics, and Post colonialism 5). Soyinka has practised all literary genres. He produced about eighteen plays, six books of fictional and nonfictional prose, five volumes of 
poetry, a work of translation, three books of critical prose and numerous pieces of cultural journalism and political arguments. Such a diverse production did not, in the least, cloud the understanding of the unified, integrated sensibility of Soyinka as an artist. Soyinka infuses his sensitivity as a gifted poet into his dramatic, fictional and nonfictional works. It is his artistic and political risk that carve out his reputation among his contemporaries. These risks emerge from his engagement with the historical and cultural conditions of his society. Soyinka's achievement in drama, in comparison to the other genres of literary expression, is "a fascinating combination and synthesis of individual talent and sensibility, formal institutional training and practical theatre experience, and the weight of received, subliminally absorbed cultural tradition." (Jeyifo 89)

3- The story of the first death, Moyo elaborates that when death first entered the world, men sent the chameleon to find out the cause; god sent the chameleon to let men know that if they threw porridge over a corpse, it would come back to life. However, chameleon was slow in returning, and death was rampant. People, therefore, decided to send another messenger, the lizard (Moyo 82). God got angry because men asked him again the same question which he had already answered so, he told the lizard that men should dig a hole and bury their dead in it. "On the way back, lizard overtook chameleon and delivered his message first. When chameleon arrived, the dead were already buried" (Moyo82)

\section{Works Cited}

Antze, Paul. "The Other Inside: Memory as Metaphor in Psychoanalysis." Regimes of

Memory. Sausannah Radsone, and Katharine Hodgkin, editors. Routledge, 2003, pp.

96-113. 
Bennett, Tony. "Stored Virtue: Memory the Body and Evolutionary Museum." Regimes of

Memory. Sausannah Radsone, and Katharine Hodgkin, editors.

Routledge, 2003, pp.40-54.

Bhabha, Homi K. The Location of Culture. Routledge, 1993.

Chamberlain, Mary and Paul Thompson. "Genre and Narrative in Life Stories." Narrative

and Genre. Chamberlain, Mary\& Paul Thompson, editors.

Routledge, 1998, pp.1-22.

Cofino, Alan. "Tales of the Revolt. Memory, Oblivion, and Identity in the Low

Countries 1566-1700."

www.hum.leiden.edu/+history/tales+of+the+Revolt/approach1.ht.1

Accessed 7 Apr. 2017.

Coser, Lewis A. "The Introduction of Maurice Halbwachs.” On

Collective Memory. Ed.\&

Trans., Lewis A. Coser, Chicago UP, 1992, pp. 1-34.

Coupe, Laurence. Myth, the New Critical Idiom. Routledge, 1997.

Crow, Brian\& Chris Banfield. Introduction to Post-Colonial Theatre.

Cambridge UP, 1996.

Cupitt, Don. The World to Come. SCM, 1982.

Davis, Ann B. "Dramatic Theory of Wole Soyinka." Critical

Perspectives on Wole Soyinka.

147- 155.

Ed. James Gibbs, Three Continents, Lynne Rienner, 1980, pp.

Fanon, Franz. "On National Culture" The Wretched of the Earth. Grove, 1963, pp.176-170.

Gibbs, James. Wole Soyinka. Grove/Atlantic, 1986.

-----"The Introduction to Critical Perspectives on Wole Soyinka." Ed.

James Gibbs. Lynne

Rienner, Three Continent, 1980, pp. 3-17.

Gray, Douglas. Five Hundred Years of Words and Sounds. DS Brewer, 1984.

Gurr, Andrew. "Third-World Drama: Soyinka and Tragedy." Critical Perspectives on Wole

Soyinka. Ed. James Gibbs. Lynne Rienner, Three Continent, 1980, pp.139-145.

Halbwachs, Maurice. On Collective Memory. Ed.\& Trans., Lewis A. Coser, Chicago UP, 
1992.

Irele, Abiola. "Tradition and The Yoruba Writer: D. O. Fagunwa, Amos Tutuola\& Wole

Soyinka.” Critical Perspectives. Ed. James Gibbs. Lynne Rienner,

Three Continents, 1980, pp.45-67

Isaiah 53:5. King James Version of the Bible, Standard Text Edition.

Izevbaye S. Dan "Mediation in Soyinka: The Case of The King's

Horseman." Critical

Perspectives on Wole Soyinka. Ed. James Gibbs. Lynne Rienner

Three Continents, 1980, pp. 116-125.

Jeyifo, Biodun. Wole Soyinka: Politics, Poetics, and Post colonialism:

Cambridge Studies in

African and Caribbean Literature. Cambridge UP, 2004.

Levi, Giovanni, “On Micro-history." New Perspectives on Historical Writing. Ed. Peter

Burke, Polity, 1991, pp.93-113.

"Memory." Online Dictionary/Memory.Glosbe.com/ Accessed, 5 June, 2017.

"Mythology." Merriam-Webster-com/thesaurus/mythology. Accessed 1st September 2018.

"Mythography." Merriam-Webster-com/dictionary/mythography.

Accessed 1st September 2018.

Mythopoeia Merriam-Webster-com/dictionary/ mythopoeia-

Mythology.Accessed.1st September 2018.

Ngugi, Wa Thiong'o. Decolonizing the Mind: The Politics of Language in African

Literature. Tames Currey.1985a.

Papoulias, Constantina.'From The Agora to the Junkyard." Regimes of Memory.

Susannah Radsone \& Katharine Hodgkin, editors. Routledge 2003, pp.114-130.

Pollmann, Judith. "Memory: Concepts and Practice." Universiteit leiden.nI/en research-

Projects /humanities/memory-concepts-and-theory tab-1 20082013.Accessed 9

March, 2018.

Shah, S (2003) The Researcher/Interviewer in Intercultural Context: a social intruder! British.

Educational Research Journal.30:4, 549-575. Last update 13-82012. Accessed 4 March 2018.

Sharp, James. "History From Below." New Perspectives on the Historical Writing. Ed. Peter 


\section{Hala Mahmoud Mohammad Harby}

Burke, Polity, 1991, pp. 51-72.

Soyinka, Wole. "Interview, Soyinka Talks to Flamingo, Flamingo, 5, 6 (1966), 16. By

Valerie Wilmer. Critical Perspectives on Soyinka. Ed. James

Gibbs, 1st ed. Lynne Rienner, Three Continents, 1980, p.4.

------Death and the King's Horseman. Richard Clay, (the Chaucer

Press), 1975.

-----“"Drama and Revolutionary Ideal." Wole Soyinka in Person: Achebe, Awooner, and

Soyinka at the University of Washington. Ed. Karen L Morell

Seattle: University of Washington African Studies Program, 1975, pp.61-89.

"An Interview with Wole Soyinka." Black World by Henry Louis

Gates Jr. 24.10

(1975), 30-48) reprinted by Henry Louis Gates, Jr. in

Conversations with Wole Soyinka. Ed. Biodun Jeyifo, Mississippi UP, 2001, pp. 48-67.

Washington

"Wole Soyinka: In Person." by Karen L.Morell, A Discussion in

University/1973. Karen L. Morell. Ed. 1975, 89-130,

Conversations with Wole Soyinka. Ed. Biodun Jeyifo, Mississippi

UP, 2001, pp. 1-31.

"Morality and Aesthetics in the ritual Archetype." Myth,

Literature, and the African

World. Cambridge UP, 1976, pp. 1-36.

------"Drama and the African world-view." Myth, Literature. And the

African World.

Cambridge UP, 1976, pp. 37-60.

“The Fourth Stage." Myth, Literature. And the African World.

Cambridge UP, 1976,

pp. 140-160.

Jane Wilkinson.

Talking with African Writers. By Jane Wilkinson. Ed. James

Curry, 1992-91-110 Reprinted/ Conversations with Wole Soyinka.

Ed. Biodun Jeyifo, Mississippi Up, 2001, pp. 143-166.

"Theatre in African Societies: Survival Patterns." Art Dialogue and

Outrage: Essays

on Literature and Culture. Methuen, 1993a, pp. 1-23. 
-_"The Transitional Politics on Human Rights." Index on Censorship vol.22 (2) $1993 b$

--------The Open Sore of a Continent: A Personal Narrative of the Nigerian Crisis. Oxford

UP, 1996.

Sutton, John. "Memory" Stanford Encyclopedia of Philosophy, Stanford University, www./,

plato.stanford.edu/entries/memory/. Accessed 15 Apr. 2017.

Suadha, K.P. Ritual of Transition in Death and the King's Horseman.

Calicut UP, 2004.

Wilson, Janelle L. Nostalgia: Sanctuary of Meaning. University of Minnesota -Duluth 2005.

Last update 2014. Accessed 9-3-2018, pp. 38-52. 